\title{
ESTIMATION OF TOTAL IgE IN THE LACRIMAL FLUID AND SERUM OF PATIENTS WITH GIANT PAPILLARY CONJUNCTIVITIS
}

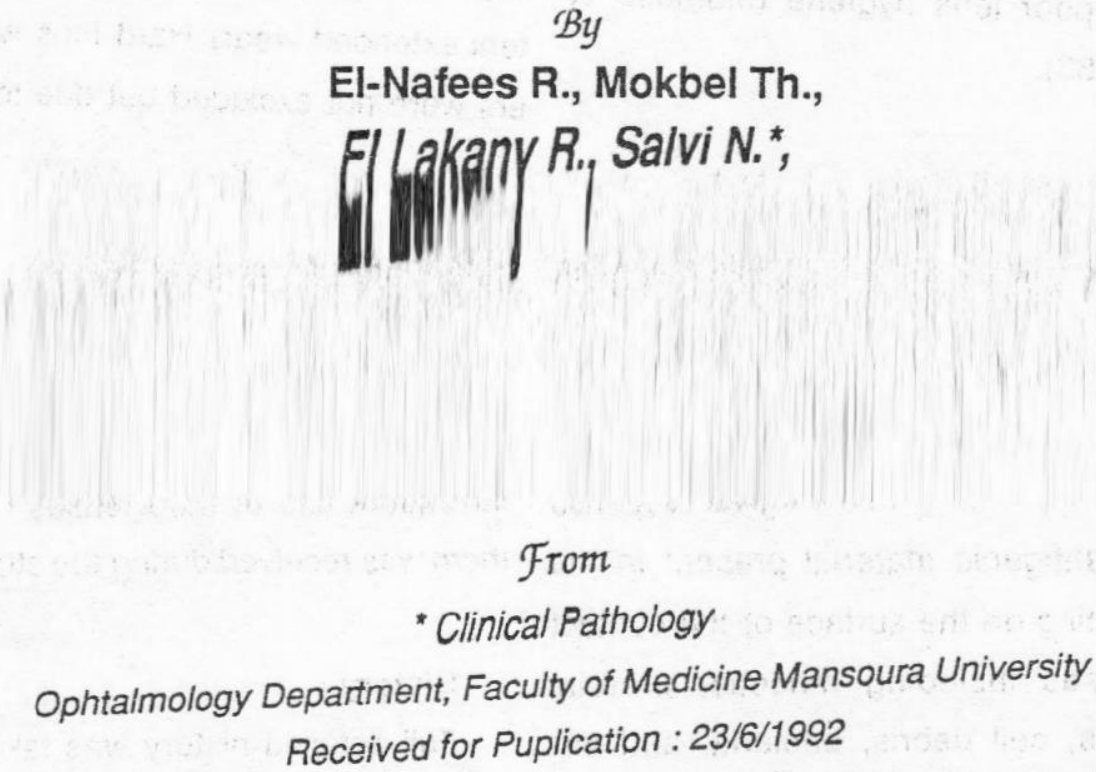

\section{INTRODUCTION}

Giant papillary conjunctivitis (GPC) is a disease of contact lens wearers, which was first reported by Spring (1974), in 78 out of 170 soft lens wearers. The disease is characterized by the appearance of giant papillae more than $1 \mathrm{~mm}$ in diameter at the upper tarsal conjunctiva with subjective symptoms including cloudiness and dislocation of the contact lens, mucoid discharge, foreign body sensation, irritation, watering, hyperaemia, and itching (Allansmith et al, 1977). The disease may occur in both hard and soft contact lens wearers but the physical appearance differs. Papillae are fewer in rigid lens GPC, and more likely have flat tops in contrast to papillae of soft lens GPC which are more rounded (Henriquez et al,1980). Biopsy specimens of the upper tarsal area showed normal conjunctiva with micropapillae and huge expansion of tissue which is mostly collagen (Korb et al, 1980). Histopathological studies showed the presence of mast cells in the conjunctival epithelium and substantia propria,eosinophils and occasionally basophils in the epthelium or substantia propria (Allansmith et al, 1978).

The aetiology of GPC is not completely clear. The possible causes include repeated mechanical irritation of the coniunctiva by the contact lens with lid movements, allergy to the lens MANSOURA MEDICAL JOURNAL 
material, history of atopy, lens depos- mal contact lens wearers were ranits, irritation by the cleaning solutions, and poor lens hygiene (Momose et al, 1983).

domly selected for this study. All were soft lens wearers(high water content,extended wear) Hard lens Weal.

A specific immunological response to antigenic material present in the coating on the surface of the contact lenses including mucous, protein, cells, cell debris, bacteria, and airborne pollutants may have a role in the development of GPC (Fowler \& Allansmith, 1988)

Takeuch et al., (1983) studied the atopic history and the $\mathrm{lg} \mathrm{E}$ values in blood for 22 patients with GPC. Atopic history was found in 7 patients and serum Ig $\mathrm{E}$ was elevated more than $500 \mathrm{lu} / \mathrm{ml}$ in 4 patients. Ig $\mathrm{E}$ values in serum and lacrimal fluid in different atopic conjunctivitis patients were found to be higher than in non-atopic conjunctivitis patients and in normal control subjects (Aalders- Deenstra etal, 1985)

\section{SUBJECTS \& METHODS}

A group of contact lens wearers having GPC and another group of norVol. 22, No. 1 \& 2 Jan. \& April 1992 ers were not excluded but due to the infrequent use of hard lenses non of them was received during the study.

\section{History :}

Full detailed history was taken including history of atopic diseases in the patient or the family, duration of contact lens use, types of lenses used, method of lens care, and the nature of symptoms.

\section{Examination :}

Full ocular examination was carried out including slit lamp examination of the anterior segment, conjunctiva, and inspection of the contact lens.

\section{Collection of lacrimal fluid :}

The lacrimal fluid was collected using a glass capillary tubes the capacity of which is $100 \mathrm{u} 1$. No surface anaesthetic was used to avoid altering the chemical composition of the lacrimal fluid. 
Each glass capillary was put in the lower fornix gently until filled, then transferred to the test tube and another one used to collect more lacrimal fluid. 500-800 u1 were collected for each patient. The lacrirnal fluid was stored in polystyrene tubes at $-70 c^{\circ}$ till analysis was carried out.

A blood sample was taken for each patient at the laboratory for the estimation of serum IgE.

\section{IgE determination :}

The total IgE content of the lacrimal fluid and serum was measured with the commercially available Phadezyn PRIST (Pharmacia - Swezerland) according to the instructions given by the manufacturer. The value is expressed in $\mathrm{IU} / \mathrm{ml}$.

\section{RESULTS}

28 GPC patients were studied. 20 were females and 8 were males. Their ages ranged between $16-40$ years. 22 normal contact lens wearers were also studied. Their ages ranged between 18-38 years. All the studied cases used soft contact lenses for a duration ranging between $3-10$ years.

\section{Atopic History :}

History of atopic diseases was detected in 8 out of the 28 GPC cases and in 2 out of the 22 normal contact lens wearers weather in the patient or the family.

\section{Lacrimal and Serum IgE :}

The results of total lacrimal and serum IgE in the GPC patients and in the normal contact lens wearers are shown in Table I.

Table I, total lacrimal and serum $\mathrm{lgE}(\mathrm{IU} / \mathrm{ml})$ in GPC patients and normal contact lens wearers.

\begin{tabular}{|c|c|c|c|c|}
\hline & \multicolumn{2}{|c|}{ GPC patients } & \multicolumn{2}{|c|}{ Normal lens wearers } \\
\hline & No. & $\%$ & No. & $\%$ \\
\hline Normal & 4 & $14.29 \%$ & 19 & $86.37 \%$ \\
\hline Elevated & 24 & $85.71 \%$ & 3 & $13.63 \%$ \\
\hline Total & 28 & $100.00 \%$ & 22 & $100.00 \%$ \\
\hline
\end{tabular}

$24(85.71 \%)$ out of the 28 GPC patients showed elevated lacrimal lgE levels (5.7 - 63.8) IU/ml and also elevated serum IgE levels (205.6 - 943.7) $\mathrm{IU} / \mathrm{ml}$. 
The remaining 4 patients showed normal lacrimal IgE levels $(0.35$ $0.56) \mathrm{IU} / \mathrm{ml}$ as well as normal serum IgE levels (16.4 - 137.6) IU/ml.

Only $3(13.63 \%)$ out of the 22 normal soft contact lens wearers showed elevated lacrimal IgE levels $(8.2,15.3$, 23.7) $\mathrm{IU} / \mathrm{ml}$ and also elevated serum IgE levels $(183,241.5,341.8) \mathrm{lu} / \mathrm{ml}$. The remaining $19(86.37 \%)$ cases showed both normal lacrimal IgE levels $(0.37-0.83) \mathrm{IU} / \mathrm{ml}$, and serum $\mathrm{lgE}$ levels $(7.6-124.8) \mathrm{IU} / \mathrm{ml}$.

\section{DISCUSSION}

Many factors have been suggested to contribute in the establishment of GPC in contact lens wearers but the exact aetiology is still not completely clear.

The possibility of being an immunological process was raised by Korb et al., (1980) depending upon the nature of cellular infiltration. The study of $\mathrm{IgE}$ in serum and in the lacrimal fluid became an important way to diagnose atopic conditions and to explain the occurrence of certain diseases on imVol. 22, No. 1 \& 2 Jan. \& April 1992 munological basis. In our study the total serum and lacrimal IgE were estimated using the PRIST which was found by Ballow \& Mendeison (1980) to be able to measure only values above $0.25 \mathrm{IU} / \mathrm{ml}$, and by Liotet et al., (1983) to measure total levels above $0.5 \mathrm{IU} / \mathrm{ml}$. A considerable elevation was detected in both lacrimal and serum total lgE in $85.7 \%$ out of 28 GPC cases, with the elevation more pronounced in the lacrimal fluid which may reflect local production of $\mathrm{IgE}$ in the lacrimal fluid. A slight elevation of total lacrimal and serum IgE was detected in only 3 out of 22 normal contact lens wearers, 2 of them had +ve atopic history but non of them had conjunctivitis. 8 out of the 28 GPC cases had +ve atopic history together with elevated IgE levels. These results show that the occurrence of GPC is not just a conjunctival response to local irritation of the lens coating, or cleaning solutions, but is rather an immunological process. The local factors can stimulate the development of type I and type IV hypersensitivity responses. Our results agree with those of $\mathrm{Ta}$ keuchi et al., (1983) who considered 
GPC a sort of immediate hypersensitivity reaction.

\section{SUMMARY}

Total Ig $E$ levels in the lacrimal fluid and serum were estimated in 28 soft contact lens wearers having giant papillary conjunctivitis (GPC) and in 22 normal soft contact lens wearers using the paper radioimmunosorbent test (PRIST).

\section{REFERENCES}

Alders - Deenstra V, Kok PTM, Bruynzeel PLB. Br J Ophthalmol $1985,69: 380-384$.

Allansmith MR, Korb DR, Greiner JV, Henriquez AS, Simon $M A$, Finnemore VM, Am J Ophthalmol 1977, 83 : 697708.

Allansmith MR, korb DR, greiner JV. Trans Am Acad Ophthalmol and Otol 1978, 85 : 766778.

Bllow M, Mendelson L. J Allergy Clin Immunol 1980; 66 : 112-118.

Fowler SA, Allansmith MR. Arch Ophthalmol 1988; 98: 95-99.

Henriquez AS, Baird RS, Korb DR, Allansmith MR. Ann Oph-
A considerable elevation of lacri$\mathrm{mal}$ and serum IgE was detected in 24 (85.71\%)out of the 28 GPC patients. The elevation was more pronounced in lacrimal than in serum lgE.

A slight elevation was detected in only $3(13.63 \%)$ out of the 22 normal contact lens wearers.

thalmol 1980,12 : $929-933$.

Korb DR, Allansmith MR, Greiner JV, Henriquez AS, Herman JP, Richmond PP, Finemore VM. Ophthalmologica 1980, 88: 1132-1136.

Liotet S, Warnet VN, Arrata M. Ophthalmologica 1983, 186: 31 34.

Momose T, Kashima K, Ito N, Nakajima A. Journal of Japan contact lens society 1983, 25: 284-290.

Spring TF. Med J Australia 1974, 1: 499.

Takeuchi $\mathrm{T}$, Tagawa $\mathrm{Y}$, Ariga $\mathrm{H}$, Mastuda H. Jap J Clin Ophthalmol $1983 ; 37: 805-810$.

MANSOURA MEDICAL JOURNAL 


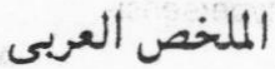

تحديد نسبة الأجسام المناعية المضادة (أى) الكلية فى السائل الدمعى الميى والدم فى مرضى التهاب الملتحمه الحلمى العملاق

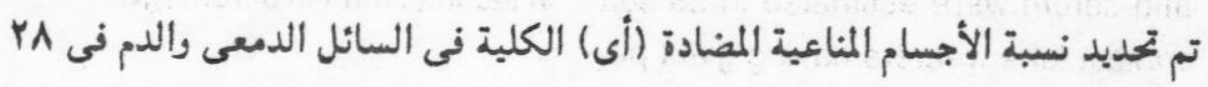

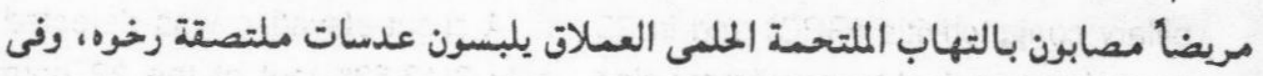

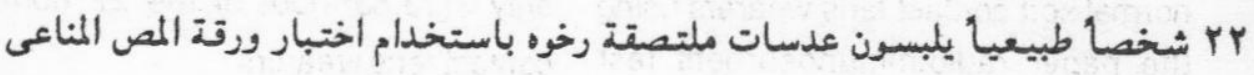

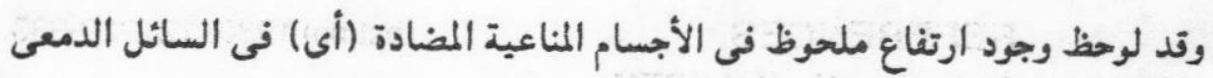

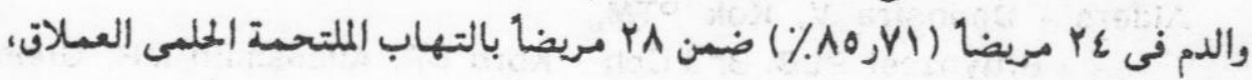

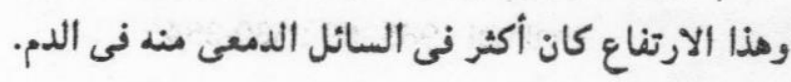

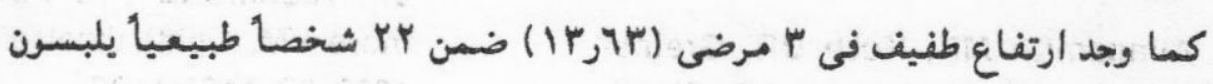
عدسات ملتصقة رخوه.

Vol. 22, No. 1 \& 2 Jan. \& April 1992 